\title{
STUDI PEMANFAATAN PRODUK RECOVERY ALUM DARI LUMPUR IPAM SEBAGAI KOAGULAN PADA PROSES KOAGULASI - FLOKULASI
}

\author{
Serly Oktaviani ${ }^{* 1)}$ dan Agus Slamet ${ }^{1)}$ \\ ${ }^{1)}$ Departemen Teknik Lingkungan,Institut Teknologi Sepuluh Nopember (ITS), \\ Kompleks Kampus ITS, Sukolilo, Surabaya, 60111 \\ ${ }^{*}$ E-mail: serlyovia@gmail.com
}

\begin{abstract}
Abstrak
Produksi lumpur unit clearator pada Instalasi Pengolahan Air Minum (IPAM) cukup besar. Lumpur dari unit clearator ini masih mengadung alumunium cukup besar. Kandungan Al dalam lumpur ini bisa dimanfaatkan kembali melalui proses recovery. Metode recovery dalam penelitian menggunakan proses asidifikasi yakni dengan menambahkan larutan asam sampai $\mathrm{pH}$ 1-3. Efektifitas Al hasil recovery sebagai koagulan diuji dengan menambahkan pada proses koagulasi-flokulasi menggunakan air baku yang sama. Penelitian dilakukan dengan variasi $\mathrm{pH}$, kecepatan dan waktu pengadukan. Variasi $\mathrm{pH}$ dilakukan pada $\mathrm{pH} 2$, 3 dan 4, sedangkan kecepatan pengadukan pada100 dan $120 \mathrm{rpm}$, dengan waktu pengadukan 30 dan 45 menit. Hasil penelitian proses recovery alum diperoleh kondisi terbaik pada $\mathrm{pH} 2$, kecepatan pengadukan $100 \mathrm{rpm}$ dengan waktu pengadukan 45 menit, menghasilkan kadar alum sebesar 3,2912 mg Al/ gram lumpur kering. Efektifitas Al recovery diuji pada proses koagulasi dan flokulasi dengan kombinasi Al recovery dan tawas asli pada variasi kekeruhan air 13 NTU, 11 NTU dan 10 NTU. Hasil penelitian terbaik pada kekeruhan air 11 NTU dengan kombinasi tawas asli dan Al recovery 3:2 menghasilkan kekeruhan akhir 0,75 NTU. Analisis perbandingan biaya pengolahan air menggunakan Al produk recovery, kombinasi dan tawas asli berturut turut sebesar $\mathrm{Rp} 32.500,-$, , Rp 13.510,-, dan $\mathrm{Rp} 850$. Proses recovery tidak layak untuk proses bisnis, namun layak untuk pengendalian pencemaran lingkungan.
\end{abstract}

Kata kunci: Alum, Lumpur, Koagulasi-Flokulasi, Recovery

\begin{abstract}
There is a relatively large amount of sludge generated at a clearator in a potable water treatment plant (IPAM). The sludge from a clearator would still contain quite a large amount of aluminum. The Al content in the sludge can be reused through the process of recovery. The method of recovery used in the research was acidification process i.e. addition of acidic liquid to reach a $\mathrm{pH}$ of 1-3. The effectiveness of Al from recovery as coagulant was tested by adding it to coagulation-flocculation process using the same standard water. Research was done by varying $\mathrm{pH}$, speed and time of stirring. $\mathrm{pH}$ variations used were 2, 3 and 4, with stirring speed varied at 100 and $120 \mathrm{rpm}$, and stirring times at 30 and 45 minutes. The results showed that optimum aluminum recovery occurred at $\mathrm{pH}$ level of 2, stirring speed of $100 \mathrm{rpm}$ and stirring time of 45 minutes, generating aluminum level of $3.2912 \mathrm{mg}$ Al per gram of dry sludge. The effectiveness of Al recovery was tested on the process of coagulation dan flocculation with a combination of recovered $A l$ and and original alum at water turbidity levels of 13 NTU, 11 NTU and 10 NTU. Research results showed that the optimum process occurred at water turbidity level of 11 NTU and a combination of original alum and recovered $\mathrm{Al}$ at 3:2 ratio, generating final turbidity of $0.75 \mathrm{NTU}$. An analysis to compare water treatment cost using recovered Al, original Alum, and a combination of both found that the costs were Rp. 32,500, Rp. 13,510, and $R p .850$ respectively. The recovery process would not be proper for bussines process, but suitable for environmental pollution control.
\end{abstract}

Keywords: Aluminum, Sludge, Coagulation-Flocculation, Recovery 


\section{PENDAHULUAN}

Lumpur merupakan produk samping dari aktivitas IPAM . Volume lumpur bergantung dengan debit air baku dan kandungan padatan total dalam air baku yang digunakan. Debit air kurang lebih $2000 \mathrm{~L} /$ detik. Lumpur yang dihasilkan dari unit sebesar $253,649 \mathrm{~m}^{3} /$ hari (Firiziqy dan Serly, 2017). Lumpur yang dihasilkan dari unit clerator memiliki kandungan alum dan akan sangat berpengaruh kepada kualitas lingkungan jika dibuang dengan jumlah yang besar (Irfan, 2007).

Disisi lain, lumpur yang dihasilkan oleh PDAM masih mengandung alum sebanyak 95,97\% yang dapat di recovery dengan asam sulfat konsentrasi $6 \mathrm{~N}$ (Wahyudin, 2001). Proses recovery alum umumnya menggunakan metode asidifikasi. Asam yang digunakan pada asidifikasi adalah $\mathrm{H}_{2} \mathrm{SO}_{4}$ dengan menggunakan variasi konsentrasi dan pH (Ruri dan Boavantura, 2000). Asidifikasi merupakan proses penambahan asam hingga mencapai pH 2 untuk melarutkan alum yang terkandung pada lumpur keluaran unit clearator (Cundari dkk., 2016). Kandungan alum ini dapat dimanfaatkan kembali pada pengolahan air minum di PDAM. Koagulasi menggunakan alum hasil proses recovery menghasilkan persen penyisihan yang cukup tinggi dibandingkan dengan alum murni. Proses recovery alum menggunakan asam sulfat sebagai pereaksi dengan konsentrasi 6 N (Wahyudin, 2001). Dalam penelitian ini akan menganilis faktor yang mempengaruhi proses recovery dengan metode asidifikasi yaitu $\mathrm{pH}$ dan kecepatan pengadukan. Alum hasil recovery akan dikombinasikan dengan tawas murni untuk substitusi proses koagulasi flokulasi.

\section{METODA}

\section{Ide Penelitian}

Ide penelitian ini berasal dari penelitian terdahulu mengenai uji kelayakan recovery alum pada lumpur hasil proses koagulasi flokulasi di IPAM. Kandungan alum pada lumpur IPAM berdasarkan penelitian cukup tinggi, sehingga memiliki potensi yang besar untuk dimanfaatkan kembali. Kondisi saat ini lumpur di IPAM masih dibuang ke sungai tanpa pengolahan lebih lanjut. Berdasarkan permasalahan tersebut maka diperlukan penelitian mengenai recovery lumpur alum PDAM yang dapat digunakan kembali untuk substitusi proses koagulasi-flokulasi.

\section{Pengumpulan Data}

Data primer yang didapatkan dari penelitian ini berasal dari hasil pengamatan analisis laboratorium. Analisis laboratorium dalam penelitian ini meliputi analisis kadar $\mathrm{Al}, \mathrm{Fe}$, kekeruhan dan $\mathrm{pH}$.

\section{Pelaksanaan Penelitian}

a) Penelitian pendahuluan

Sebelum proses recovery alum dengan metode asidifikasi menggunakan asam sulfat, perlu dilakukan penelitian pendahuluan terlebih dahulu terhadap sampel yang digunakan. Hal ini untuk mengetahui kondisi awal sampel. Parameter yang diuji pada penenelitian pendahuluan ini antara lain :
a. Kadar Al dalam lumpur
b. Kadar solid dan kadar air
c. pH lumpur

b) Recovery alum

Pada proses ini kandungan alum yang terdapat pada lumpur PDAM di-recovery sehingga dapat digunakan kembali untuk substitusi proses koagulasi-flokuasi. Proses recovery alum menggunakan metode asidifikasi dengan asam sulfat. Pada tahap ini menentukan $\mathrm{pH}$ optimum asam sulfat serta kecepatan pengadukan dan waktu optimum yang dapat menghasilkan nilai recovery alum yang maksimal. Variasi $\mathrm{pH}$ yang digunakan adalah 1-4. Variasi kecepatan dan lama pengadukan yang digunakan adalah $100 \mathrm{rpm}$ 30 menit, 100 rpm-45 menit, 120 rpm-30 
menit, dan $120 \mathrm{rpm} / 45$ menit. Langkah dalam proses asidifikasi adalah sebagai berikut:

- Proses asidifikasi dengan jar-test

Proses asidifikasi merupakan tahap awal dalam recovery alum dengan langkah-langkah sebagai berikut:

1. Lumpur dikeringkan terlebih dahulu dengan menggunakan oven.

2. Penambahan asam sulfat untuk mencapai $\mathrm{pH}$ 1-4. Massa lumpur yang digunakan adalah 30 gr pada volume $300 \mathrm{ml}$.

3. Pengadukan menggunakan peralatan jartest dengan variasi kecepatan dan waktu pengadukan $100 \mathrm{rpm}-30$ menit, $100 \mathrm{rpm}-$ 45 menit, 120 rpm-30 menit, dan 120 $\mathrm{rpm} / 45$ menit.

4. Pengendapan lumpur selama 30 menit, kemudian mengambil bagian filtratnya. Filtrat ini akan digunakan pada proses koagulasi flokulasi.

- Analisis akhir

Untuk mengetahui keberhasilan proses recovery alum dilakukan analisis pada setiap variasi lumpur yang telah terasidifikasi. Analisa akhir ini menggunakan ICP untuk mengetahui kadar Al. Parameter yang dianalisa antara lain:

a. Kadar Al filtrat pada setiap variasi

b. Volume filtrat

c) Substitusi proses koagulasi-flokuasi

Pada tahap ini menentukan konsentrasi dosis optimum kombinasi tawas murni dengan alum recovery untuk substitusi proses koagulasi-flokulasi. Sebelum proses koagulasi-flokulasi diperlukan analisa karakteristik awal air baku yang akan digunakan. Parameter yang diuji antara lain kekeruhan, alkalinitas dan $\mathrm{pH}$. Proses koagulasi-flokulasi menggunakan jar-test sebagai reaktor untuk menentukan dosis optimum kombinasi tawas murni dan tawas hasil recovery. Dosis yang digunakan pada tawas murni dan alum recovery yaitu 35 $\mathrm{mg} / \mathrm{L}, 40 \mathrm{mg} / \mathrm{L}, 45 \mathrm{mg} / \mathrm{L}, 50 \mathrm{mg} / \mathrm{L}, 55 \mathrm{mg} / \mathrm{L}$, $60 \mathrm{mg} / \mathrm{L}$. Variasi pada kombinasi antara tawas murni dengan produk recovery yaitu 1:4, 2:3, $1: 1,3: 2$ dan $4: 1$.

\section{Pengolahan Data}

a) Perhitungan hasil recovery alum

Konsentrasi optimum asam sulfat yang dapat digunakan pada penelitian ini diketahui dari seberapa banyak kandungan alum yang dihasilkan. Variasi $\mathrm{pH}$ asam sulfat yang digunakan pada penelitian ini adalah 1 dan 2, serta variasi kecepatan pengadukan $100 \mathrm{rpm}$ 30 menit, 100 rpm-45 menit, 120 rpm-30 menit, dan $120 \mathrm{rpm} / 45$ menit. Kemudian dibuat grafik untuk menentukan titik optimum dimana asam sulfat dapat me-recovery lumpur dengan melihat nilai parameter uji. Parameter yang digunakan antara lain:

- Kadar Al filtrat pada setiap variasi

- Volume filtrat

- Kadar solid

- Kadar air

b) Perhitungan dosis optimum kombinasi alum recovery dengan tawas murni untuk subtsitusi proses koagulasi flokulasi

Kemampuan kombinasi tawas murni dan alum recovery dalam proses koagulasiflokulasi dilakukan perhitungan nilai kekeruhan dan $\mathrm{pH}$ di awal serta menguji kekeruhan dan $\mathrm{pH}$ sesudah proses koagulasiflokulasi. Hasil perhitungan dibuat dalam bentuk grafik.

\section{HASIL DAN PEMBAHASAN}

\section{Analisis Proses Recovery Alum}

Pada analisis pendahuluan didapatkan karakteristik lumpur awal sebagai berikut:

Kadar solid lumpur : 18,38\%

Kadar air lumpur : 81,62\%.

Pada penelitian ini asam yang digunakan adalah asam sulfat $\left(\mathrm{H}_{2} \mathrm{SO}_{4}\right)$. Lumpur yang digunakan pada penelitian ini berupa lumpur basah dari unit holding tank. Lumpur dikeringkan di dalam oven $105^{\circ} \mathrm{C}$ selama satu hari. Lumpur kering ditumbuk hingga halus kemudian ditimbang dengan perbandingan konsentrasi pada larutan 10\%. Lumpur kering 
dilarutkan dengan aquades kemudian ditambahkan asam sulfat dengan volume tertentu hingga mencapai pH 2, 3 dan 4. Larutan lumpur diaduk dengan menggunakan jartest sesuai dengan variabel penelitian yang digunakan yaitu variasi kecepatan pengadukan $100 \mathrm{rpm}-30$ menit, $100 \mathrm{rpm}-45$ menit, $120 \mathrm{rpm}-30$ menit, dan $120 \mathrm{rpm} / 45$ menit.

Sampel lumpur yang digunakan dalam penelitian ini mengandung $\mathrm{Al}(\mathrm{OH})_{3} \cdot \mathrm{Al}(\mathrm{OH})_{3}$ merupakan senyawa yang bersifat amfotir. Pada kondisi ini $\mathrm{Al}(\mathrm{OH})_{3}$ sebagai basa lemah. Asam sulfat yang ditambahkan ke dalam air akan mengalami ioniasi melepaskan ion $\mathrm{H}+$ dengan reaksi sebagai berikut:

$$
\mathrm{H}_{2} \mathrm{SO}_{4} \longrightarrow 2 \mathrm{H}^{+}+\mathrm{SO}_{2-}
$$

Ion $\mathrm{H}^{+}$yang terlepas akan menguraikan $\mathrm{Al}$ yang terkandung pada $\mathrm{Al}(\mathrm{OH})_{3}$, sehingga menjadi $\mathrm{Al}^{3+} . \mathrm{Al}^{3+}$ akan berikatan dengan ion sulfat dan akan menghasilkan garam alumunium sulfat. Reaksi yang dihasilkan adalah sebagai berikut:

$$
2 \mathrm{Al}(\mathrm{OH})_{3(\mathrm{~s})}+3 \mathrm{H}_{2} \mathrm{SO}_{4(\mathrm{aq})} \rightarrow \mathrm{l}_{2}\left(\mathrm{SO}_{4}\right)_{3(\mathrm{aq})}+
$$

$6 \mathrm{H}_{2} \mathrm{O}_{(1)}$

Pada peneletian ini menggunakan asam sulfat dengan konsentrasi $4 \mathrm{~N}$. Hasil analisis proses asidifikasi dapat dilihat pada Tabel 1. Salah satu faktor yang mempengaruhi proses asidifikasi adalah kecepatan pengadukan. Berdasarkan data penelitian Gambar 1 tampak bahwa kadar Al bervariasi pada kecepatan pengadukan. Namun, Gambar 1 terlihat bahwa kadar Al maksimal berada pada kecepatan 100 rpm, Gtd 378000 pH 2 dengan kadar 515,1 mg/L. Kandungan alum ini terhitung masih rendah karena hanya ada 5,15 mg dalam satu gram berat kering lumpur. Namun, hal ini masih memberikan peluang untuk dimanfaatkan kembali.

\begin{tabular}{|c|c|c|c|c|c|c|c|}
\hline No & $\mathrm{pH}$ & GTD & $\begin{array}{c}\text { Volume } \\
\text { pembubuhan } \\
\text { Asam Sulfat } \\
\text { (ml) }\end{array}$ & $\begin{array}{l}\text { Volume } \\
\text { filtrat }\end{array}$ & $\begin{array}{c}\text { Kadar Al } \\
(\mathrm{mg} / \mathrm{L})\end{array}$ & $\begin{array}{c}\text { Berat } \\
\text { kering }(g)\end{array}$ & $\begin{array}{c}\text { kadar Al } \\
\text { dalam } \\
\text { berat } \\
\text { kering } \\
(\mathrm{mg} / \mathrm{g}) \\
\end{array}$ \\
\hline 1 & 2 & 252000 & 10 & 235 & 130,2 & 30 & 1,302 \\
\hline 2 & 2 & 378000 & 11 & 230 & 445,9 & 30 & 4,459 \\
\hline 3 & 2 & 331200 & 10 & 235 & 457,9 & 30 & 4,579 \\
\hline 4 & 2 & 496800 & 11 & 225 & 184,9 & 30 & 1,849 \\
\hline 5 & 3 & 252000 & 2,6 & 230 & 0,231 & 30 & 0,0023 \\
\hline 6 & 3 & 378000 & 3,3 & 235 & 1,549 & 30 & 0,0155 \\
\hline 7 & 3 & 331200 & 3,3 & 225 & 33,76 & 30 & 0,3376 \\
\hline 8 & 3 & 496800 & 2,6 & 230 & 1,148 & 30 & 0,0115 \\
\hline 9 & 4 & 252000 & 2,5 & 235 & 0,123 & 30 & 0,0012 \\
\hline 10 & 4 & 378000 & 2 & 225 & 0,925 & 30 & 0,0093 \\
\hline 11 & 4 & 331200 & 1,9 & 230 & 1,284 & 30 & 0,0128 \\
\hline 12 & 4 & 496800 & 1,9 & 235 & 0,861 & 30 & 0,0086 \\
\hline
\end{tabular}

Tabel 1. Hasil analisis $\mathrm{Al}^{3+}$

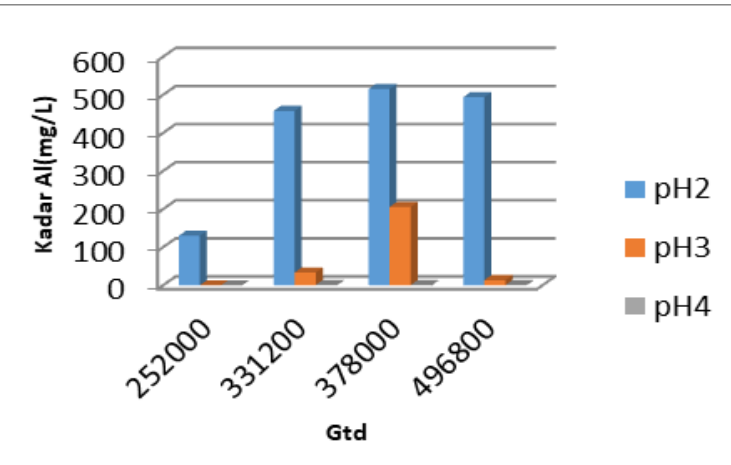

Gambar 1. Perbandingan Gtd dengan produk recovery $(\mathrm{mg} / \mathrm{L})$

Data penelitian menunjukan bahwa kecepatan pengadukan tidak berbanding lurus dengan kadar Al. Faktor $\mathrm{pH}$ dan waktu pengadukan saling berhubungan satu sama lain, sehingga tidak dapat diputuskan semakin cepat semakin baik. Apabila semakin cepat kadar Al yang tersisa pada filtrat akan ikut menjadi flok, sehingga Al yang tersisa dalam filtrat akan semakin sedikit. Proses asidifikasi bertujuan untuk melepaskan kembali ion Al pada lumpur padat menuju bagian filtrat atau melarutnya logam alumunium oleh asam. Pada kecepatan diatas 100 rpm kadungan Al mengalami penurunan. Ketepatan dalam menentukan gradien kecepatan 
mempengaruhi kadar Al yang dihasilkan. Oleh karena itu, gradien kecepatan merupakan hal penting dalam proses pengadukan. Pada penelitian ini didapatkan nilai gradien kecepatan yang sesuai yaitu 140/dt, dimana diameter pengadukan yaitu $0,07 \mathrm{~m}$ dengan perhitungan pada masingmasing variasi sebagai berikut:

$$
\begin{aligned}
& D i=\left(\frac{P}{K_{T} n^{3} p}\right)^{1 / 5} \\
& 0,07 m=\left(\frac{P}{2,25 \times 1,667^{3} \times 997}\right)^{1 / 5} \\
& \mathrm{P} \quad=0.0174 \mathrm{~N} \cdot \mathrm{m} / \mathrm{det} \\
& G=\sqrt{\frac{P}{u \times V}} \\
& G=\sqrt{\frac{0.0174 N . m . m^{2}}{0.00089 N . \operatorname{det} \times 0.001 \mathrm{~m}^{3}}} \\
& \mathrm{G}=140 / \mathrm{det} \\
& \mathrm{Gtd}=\mathrm{G} \times \mathrm{td}=140 \times 45=378.000
\end{aligned}
$$

Tabel 2. Hasil Perhitungan G dan Gtd

\begin{tabular}{cccc}
\hline $\begin{array}{c}\text { td } \\
\text { (menit) }\end{array}$ & $\begin{array}{c}\text { Kecepatan } \\
\text { pengadukan } \\
\text { (rpm) }\end{array}$ & $\begin{array}{c}\mathrm{G} \\
(1 / \mathrm{det})\end{array}$ & $\mathrm{Gtd}$ \\
\hline 30 & 100 & 140 & 252.000 \\
45 & 100 & 140 & 378.000 \\
30 & 120 & 184 & 331.200 \\
45 & 120 & 184 & 496.800 \\
\hline
\end{tabular}

Hasil rata-rata karakteristik lumpur harian dengan menggunakan metode asidifikasi $\mathrm{pH} 2$ dan Gtd 378.000 dapat dilihat pada Tabel 3.
Tabel 3. Karakteristik lumpur harian

\begin{tabular}{cccccc} 
Tanggal & $\begin{array}{c}\text { Kadar } \\
\text { Air }\end{array}$ & $\begin{array}{c}\text { Kadar } \\
\text { Berat } \\
\text { kering }\end{array}$ & $\begin{array}{c}\text { Kadar Al } \\
(\mathrm{mg} / \mathrm{L})\end{array}$ & $\begin{array}{c}\text { Berat } \\
\text { kering } \\
(\mathrm{g})\end{array}$ & $\begin{array}{c}\text { kadar Al } \\
\text { dalam berat } \\
\text { kering (mg/g) }\end{array}$ \\
\hline 07-Mar-18 & $69.2 \%$ & $31 \%$ & 403,6 & 30 & 4,036 \\
08-Mar-18 & $59.4 \%$ & $41 \%$ & 307,8 & 30 & 3,078 \\
09-Mar-18 & $66.3 \%$ & $34 \%$ & 287,2 & 30 & 2,872 \\
10-Mar-18 & $63.7 \%$ & $36 \%$ & 332,2 & 30 & 3,322 \\
11-Mar-18 & $68.5 \%$ & $31 \%$ & 392,3 & 30 & 3,923 \\
12-Mar-18 & $71.2 \%$ & $29 \%$ & 251,6 & 30 & 2,516 \\
Rata-rata & $66.4 \%$ & $34 \%$ & 329,11 & 30 & 3,291
\end{tabular}

\section{Analisis proses koagulasi-flokulasi dengan tawas asli}

Air baku diambil selama 3 kali untuk mendapatkan kualitas air yang berbeda. Hasil analisis air baku yang digunakan untuk proses koagulasi-flokulasi dapat dilihat pada Tabel 4.

Tabel 4. Kualitas air baku

\begin{tabular}{cccc}
\hline & $\begin{array}{c}\text { Air } \\
\text { Baku } \\
\text { I }\end{array}$ & $\begin{array}{c}\text { Air } \\
\text { Baku } \\
\text { II }\end{array}$ & $\begin{array}{c}\text { Air } \\
\text { Baku III }\end{array}$ \\
\hline $\begin{array}{c}\text { Kekeruhan air } \\
\text { baku (NTU) } \\
\text { pH }\end{array}$ & 36 & 33 & 18 \\
$\begin{array}{c}\text { Kekeruhan awal } \\
\text { (efluen } \\
\text { prasedimentasi) } \\
\text { (NTU) }\end{array}$ & 13 & 11 & 10 \\
\hline
\end{tabular}

Tabel 5. Data analisis koagulan tawas asli Air Baku I

\begin{tabular}{cccccc}
\hline $\begin{array}{c}\text { Dosis } \\
\text { (ppm) }\end{array}$ & $\begin{array}{c}\mathrm{pH} \\
\text { awal }\end{array}$ & $\begin{array}{c}\text { pH setelah } \\
\text { penambahan } \\
\text { koagulan }\end{array}$ & $\begin{array}{c}\mathrm{pH} \\
\text { akhir }\end{array}$ & $\begin{array}{c}\text { Kekeru } \\
\text { han } \\
\text { (NTU) }\end{array}$ & $\begin{array}{c}\text { Persen } \\
\text { removal }\end{array}$ \\
\hline & & & & & \\
35 & 7,18 & 6,25 & 6,46 & 2,7 & $79,23 \%$ \\
40 & 7,19 & 6,32 & 6,5 & 2,4 & $81,54 \%$ \\
45 & 7,29 & 6,3 & 6,32 & 2,4 & $81,54 \%$ \\
50 & 7,43 & 6,24 & 6,25 & 2,5 & $80,77 \%$ \\
55 & 7,50 & 6,07 & 6,22 & 2,6 & $80,00 \%$ \\
60 & 7,54 & 6,06 & 6,14 & 2,7 & $79,23 \%$ \\
\hline
\end{tabular}


Tabel 5 menunjukan pengaruh koagulan terhadap $\mathrm{pH}$ mengalami penurunan setelah penambahan koagulan dan setelah proses koagulasi-flokulasi mengalami kenaikan. $\mathrm{pH}$ mengalami penurunan karena adanya $\mathrm{H}^{+}$pada proses koagulasi-flokulasi. Dosis optimum tawas asli berada pada rentang $40-45 \mathrm{mg} / \mathrm{L}$ dengan kekeruhan awal 13 NTU dan kekeruhan akhir 2,4 NTU.

Tabel 6. Data analisis koagulan tawas asli air baku II

\begin{tabular}{cccccc}
\hline $\begin{array}{c}\text { Dosis } \\
\text { (ppm) }\end{array}$ & pH awal & $\begin{array}{c}\text { pH setelah } \\
\text { penambahan } \\
\text { tawas }\end{array}$ & $\begin{array}{c}\mathrm{pH} \\
\text { akhir }\end{array}$ & $\begin{array}{c}\text { NTU } \\
\text { akhir }\end{array}$ & $\begin{array}{c}\text { Persen } \\
\text { removal }\end{array}$ \\
\hline 35 & 7,56 & 7,19 & 7,24 & 4,2 & $61,82 \%$ \\
40 & 7,74 & 7,01 & 7,25 & 4,1 & $62,73 \%$ \\
45 & 7,73 & 6,86 & 7,21 & 4,1 & $62,73 \%$ \\
50 & 7,67 & 7,24 & 7,25 & 3,4 & $69,09 \%$ \\
55 & 7,66 & 7,06 & 7,23 & 3,8 & $65,45 \%$ \\
60 & 7,49 & 6,93 & 7,11 & 5,1 & $53,64 \%$ \\
\hline
\end{tabular}

Tabel 6 menunjukan bahwa penambahan koagulan mempengaruhi $\mathrm{pH}$ pada air baku. $\mathrm{pH}$ air baku mengalami penurunan setelah penambahan tawas asli, namun masih berada pada rentang normal sehingga tidak perlu ditambah kapur. $\mathrm{pH}$ mengalami peningkatan setelah proses koagulasi-flokulasi. Dosis optimum tawas asli yaitu $50 \mathrm{mg} / \mathrm{L}$ dengan kekeruhan awal 11 NTU dan kekeruhan akhir 3,4 dengan persen removal 69,09\%.

Tabel 7. Data analisis koagulan tawas asli Air Baku III

\begin{tabular}{cccccc}
\hline \multicolumn{6}{c}{ Baku III } \\
$\begin{array}{ccccc}\text { Dosis } \\
(\mathrm{ppm})\end{array}$ & $\begin{array}{c}\mathrm{pH} \\
\text { awal }\end{array}$ & $\begin{array}{c}\text { pH setelah } \\
\text { penambahan } \\
\text { tawas }\end{array}$ & $\begin{array}{c}\mathrm{pH} \\
\text { akhir }\end{array}$ & $\begin{array}{c}\text { NTU } \\
\text { akhir }\end{array}$ & $\begin{array}{c}\text { Persen } \\
\text { removal }\end{array}$ \\
\hline 35 & 7,76 & 6,3 & 6,4 & 3,4 & $66 \%$ \\
40 & 7,74 & 6,16 & 6,29 & 3,3 & $67 \%$ \\
45 & 7,72 & 6,16 & 6,23 & 3,1 & $69 \%$ \\
50 & 7,61 & 6,13 & 6,26 & 3,1 & $69 \%$ \\
55 & 7.56 & 6.7 & 7,04 & 3 & $70 \%$ \\
60 & 7.47 & 6.76 & 6,95 & 2,6 & $74 \%$ \\
\hline
\end{tabular}

Tabel 7 menyatakan bahwa koagulan sangat berpengaruh terhadap nilai $\mathrm{pH}$ air baku. Nilai $\mathrm{pH}$ akan menurun bila ditambah dengan koagulan dan akan mengalami kenaikan kembali setelah proses koagulasi-flokulasi. Dosis tawas optimum berbeda dengan grafik air baku sebelumnya. Dosis tawas berbanding lurus dengan kekeruhan air baku semakin banyak dosis yang diberikan semakin besar penurunan kekeruhan yaitu $74 \%$.

\section{Analisis proses koagulasi-flokulasi dengan produk recovery}

Proses koagulasi-flokulasi dengan menggunakan produk recovery dengan konsentrasi yang digunakan berdasarkan dosis terendah pada rata-rata kadar $\mathrm{Al}$ dalam lumpur harian pada Tabel 3 diperoleh hasil sebagai berikut:

Tabel 8. Hasil analisis koagulan produk recovery air baku I

\begin{tabular}{cccccc}
\hline $\begin{array}{c}\text { Dosis } \\
(\mathrm{ppm})\end{array}$ & $\begin{array}{c}\mathrm{pH} \\
\text { Awal }\end{array}$ & $\begin{array}{c}\mathrm{pH} \text { setelah } \\
\text { penambahan } \\
\text { koagulan }\end{array}$ & $\begin{array}{c}\mathrm{pH} \\
\mathrm{akhir}\end{array}$ & $\begin{array}{c}\text { NTU } \\
\text { akhir }\end{array}$ & $\begin{array}{c}\text { Persen } \\
\text { removal }\end{array}$ \\
\hline 35 & 7,57 & 6,87 & 7,21 & 2,5 & $80,77 \%$ \\
40 & 7,74 & 6,76 & 6,95 & 2,1 & $83,85 \%$ \\
45 & 7,59 & 6,93 & 6,99 & 2,1 & $83,85 \%$ \\
50 & 7,32 & 6,68 & 6,95 & 2 & $84,62 \%$ \\
55 & 7,4 & 6,95 & 7,06 & 2 & $84,62 \%$ \\
60 & 7,49 & 6,83 & 7,1 & 2,1 & $83,85 \%$ \\
\hline
\end{tabular}

Berdasarkan Tabel 8 dengan kekeruhan awal 13 NTU menunjukan nilai optimum 2 NTU dengan konsentrasi koagulan sebesar 50-55 $\mathrm{mg} / \mathrm{L}$. Nilai efisiensi removalnya yaitu $84,62 \%$. Proses koagulasi-flokulasi dengan menggunakan koagulan produk recovery mengakibatkan penurunan $\mathrm{pH}$ pada sampel namun pada kondisi ini penurunan $\mathrm{pH}$ tidak melebihi batas minimum sehingga tidak diperlukan penambahan $\mathrm{Ca}(\mathrm{OH})_{2}$ 
Tabel 9. Hasil analisis koagulan produk recovery Air baku II

\begin{tabular}{|cccccc}
\hline $\begin{array}{c}\text { Dosis } \\
(\mathrm{ppm})\end{array}$ & $\begin{array}{c}\mathrm{pH} \\
\text { awal }\end{array}$ & $\begin{array}{c}\text { pH setelah } \\
\text { penambahan } \\
\text { produk } \\
\text { recovery }\end{array}$ & $\begin{array}{c}\mathrm{pH} \\
\text { akhir }\end{array}$ & $\begin{array}{c}\text { NTU } \\
\text { akhir }\end{array}$ & $\begin{array}{c}\text { Persen } \\
\text { removal }\end{array}$ \\
\hline 35 & 7,67 & 6,4 & 6,59 & 1 & $90,91 \%$ \\
40 & 7,64 & 6,41 & 6,43 & 1 & $90,91 \%$ \\
45 & 7,63 & 6,3 & 6,35 & 0,75 & $93,18 \%$ \\
50 & 7.59 & 6,12 & 6,23 & 0,8 & $92,73 \%$ \\
55 & 7,5 & 6,09 & 6,2 & 1,5 & $86,36 \%$ \\
60 & 7,37 & 6,24 & 6,26 & 1,9 & $82,73 \%$ \\
\hline
\end{tabular}

Tabel 9 menunjukan bahwa penambahan koagulan menyebabkan penurunan pada $\mathrm{pH}$. Namun, setelah melalui proses koagulasiflokulasi nilai $\mathrm{pH}$ akan mengalami kenaikan. Kondisi pH air baku III setelah penambahan produk recovery tidak mengalami penurunan melebihi batas sehingga tidak diperlukan penambahan $\mathrm{Ca}(\mathrm{OH})_{2}$. Dosis optimum pada produk recovery dengan nilai kekeruhan awal 11 NTU dan kekeruhan akhir 0,75 adalah 45 $\mathrm{mg} / \mathrm{L}$.

Tabel 10. Hasil Analisi Koagulan produk recovery Air baku III

\begin{tabular}{|c|c|c|c|c|c|c|}
\hline $\begin{array}{l}\text { Dosis } \\
(\mathrm{ppm})\end{array}$ & $\begin{array}{c}\mathrm{pH}-1 \\
(\mathrm{pH} \\
\text { Awal) }\end{array}$ & $\begin{array}{c}\text { pH-2 } \\
\text { (Penambahan } \\
\text { Produk } \\
\text { recovery) }\end{array}$ & $\begin{array}{c}\mathrm{pH}-3(\mathrm{pH} \\
\text { akhir) }\end{array}$ & $\begin{array}{l}\text { NTU } \\
\text { Akhir }\end{array}$ & $\begin{array}{l}\text { NTU } \\
\text { Akhir }\end{array}$ & $\begin{array}{l}\text { Persen } \\
\text { Removal }\end{array}$ \\
\hline 35 & 7,84 & 5,59 & 6,07 & 6,3 & 0,9 & $91 \%$ \\
\hline 40 & 7,75 & 5,55 & 6,07 & 6,28 & 0,9 & $91 \%$ \\
\hline 45 & 7,55 & 5,51 & 6,09 & 6,26 & 0,9 & $91 \%$ \\
\hline 50 & 7,62 & 5,31 & 6,08 & 6,31 & 0,8 & $92 \%$ \\
\hline 55 & 7,56 & 4,77 & 6,14 & 6,36 & 0,75 & $92,50 \%$ \\
\hline 60 & 7,51 & 4,86 & 6,15 & 6,45 & 0,95 & $90,50 \%$ \\
\hline
\end{tabular}

Dosis optimum produk recovery dengan nilai kekeruhan awal 10 NTU dan kekeruhan akhir $0,75 \mathrm{NTU}$ adalah $50 \mathrm{mg} / \mathrm{L}$. Kondisi $\mathrm{pH}$ air baku III setelah penambahan koagulan tidak mengalami penurunan yang cukup jauh hingga melewati batas minimum, sehingga tidak diperlukan tambahan kapur untuk menaikan $\mathrm{pH}$ agar reaksi berjalan optimum.
Koagulasi-flokulasi dengan menggunakan koagulan produk recovery mengakibatkan penurunan $\mathrm{pH}$ hingga karena dosisnya produk recovery tidak terlalu tinggi dan kondisi $\mathrm{pH}$ tidak berada dibawah batas minimum, sehingga tidak perlu ditambahkan dengan $\mathrm{Ca}(\mathrm{OH})_{2}$.

Berdasarkan hasil analisa pada proses koagulasi-flokulasi terjadi penurunan $\mathrm{pH}$ setelah penambahan koagulan. Hal ini terjadi karena adanya reaksi yang berlangsung sebagai berikut:

$$
\mathrm{Al}_{2}\left(\mathrm{SO}_{4}\right)+6 \mathrm{H}_{2} \mathrm{O} \rightarrow \mathrm{Al}(\mathrm{OH})_{3}+6 \mathrm{H}^{+}+\mathrm{SO}_{4}{ }^{2-}
$$

Reaksi ini menyebabkan pelepasan ion $\mathrm{H}^{+}$ sehingga menyebabkan penurunan $\mathrm{pH}$ setelah penambahan koagulan (Fitri, 2012).

Penentuan dosis yang optimum seperti contoh pada Tabel 10 dosis optimumnya adalah 55 $\mathrm{mg} / \mathrm{L}$, setelah melebihi dosis tersebut, kekeruhan air meningkat kembali. Hal ini dikarenakan adanya flok yang berlebihan sehingga menyebabkan kenaikan kekeruhan (Sutapa, 2014). Sehingga untuk menentukan dosis optimumnya harus sesuai, tidak boleh kurang ataupun lebih karena hasilnya tidak baik.

Berdasarkan data di atas, kekeruhan akhir setelah proses koagulasi dapat diturunkan dengan menggunakan tawas asli maupun dari produk recovery sesuai dengan baku mutu Permenkes No. 492 Tahun 2010 yaitu sebesar 5 NTU. 
Analisis efisiensi removal antara tawas asli, produk recovery, dan kombinasi keduanya

Tabel 11. Hasil analisa kandungan Fe total pada filtrat lumpur

\begin{tabular}{cccccc}
\hline No & Gtd & $\mathrm{pH}$ & $\begin{array}{c}\text { Kadar } \\
\mathrm{Fe} \\
(\mathrm{mg} / \mathrm{L})\end{array}$ & $\begin{array}{c}\text { Berat } \\
\text { kering } \\
(\mathrm{g})\end{array}$ & $\begin{array}{c}\text { kadar Al } \\
\text { dalam } \\
\text { berat } \\
\text { kering } \\
(\mathrm{mg} / \mathrm{g})\end{array}$ \\
\hline 1 & 252.000 & 3 & 0,0607 & 30 & 0,000607 \\
2 & 378.000 & 3 & 0,3744 & 30 & 0,003744 \\
3 & 331.200 & 3 & 0,5264 & 30 & 0,005264 \\
4 & 496.800 & 3 & 0,3032 & 30 & 0,003032 \\
\hline
\end{tabular}

Tabel 11 menunjukan kandungan $\mathrm{Fe}$ pada filtrat hasil proses recovery. Kandungan besi menunjukkan adanya $2 \mathrm{FeSO}_{4}$ yang merupakan salah satu jenis koagulan. Oleh karena itu, pada proses koagulasi-flokulasi dengan menggunakan produk recovery memiliki tingkat penurunan kekeruhan lebih besar dibandingkan dengan tawas biasa.

Tabel 12. Perbandingan hasil pengolahan antara produk recovery dengan tawas asli

\begin{tabular}{rrrrrrrr}
\hline & \multicolumn{2}{c}{ Air Bakul } & \multicolumn{2}{c}{ Air Bakull } & \multicolumn{2}{c}{ Air Baku III } \\
Dosis(ppm) & $\begin{array}{c}\text { Produk } \\
\text { Recovery(NTU) }\end{array}$ & $\begin{array}{c}\text { Tawas } \\
\text { Asli(NTU) }\end{array}$ & $\begin{array}{c}\text { Produk } \\
\text { Recovery } \\
\text { (NTU0 }\end{array}$ & $\begin{array}{c}\text { Tawas } \\
\text { Asli(NTU) }\end{array}$ & $\begin{array}{c}\text { Produk } \\
\text { Recovery(NTU) }\end{array}$ & $\begin{array}{c}\text { Tawas } \\
\text { Asli(NTU) }\end{array}$ \\
\hline 35 & 2.5 & 2.7 & 1 & 4.2 & 0.9 & 3. \\
40 & 2.1 & 2.4 & 1 & 4.1 & 0.9 & 3. \\
45 & 2.1 & 2.4 & 0.75 & 4.1 & 0.9 & 3. \\
50 & 2 & 2.5 & 0.8 & 3.4 & 0.8 & 3. \\
55 & 2 & 2.6 & 1.5 & 3.8 & 0.75 & \\
60 & 2.1 & 2.7 & 1.9 & 5.1 & 0.95 & 2. \\
\hline
\end{tabular}

Tabel 12 menunjukan bahwa efisiensi penyisihan koagulan dengan menggunakan produk recovery lebih tinggi dibandingkan dengan menggunkan tawas asli. Hal ini dapat terjadi karena pada proses asidifikasi logam lain yang terkandung dalam lumpur ikut terlarut seperti besi sehingga menghasilkan $2 \mathrm{FeSO}_{4}$. $2 \mathrm{FeSO}_{4}$ yang merupakan salah satu jenis koagulan, sehingga dapat membantu lebih cepat dan lebih baik dalam penurunan kekeruhan karena adanya 2 jenis koagulan. Koagulan ferro sulfat membutuhkan alkalinitas dalam bentuk ion hidroksida agar menghasilkan reaksi yang lebih cepat (Masduqi dan Abdu, 2012). Oleh karena itu, $\mathrm{Ca}(\mathrm{OH})_{2}$ ditambahkan untuk meningkatkan $\mathrm{pH}$ dan alkalinitas untuk mempercepat reaksi. Penambahan $\mathrm{Ca}(\mathrm{OH})_{2}$ selain untuk meningkatkan $\mathrm{pH}$ juga dapat mempercepat proses pembentukan flok karena $\mathrm{Ca}(\mathrm{OH})_{2}$ mengikat flok-flok yang sempurna menjadi lebih sempurna sehingga massa flok lebih besar dan cepat mengendap.

Tabel 13 menunjukan bahwa berdasarkan hasil percobaan kombinasi perbandingan yang paling baik untuk masing- masing variasi air baku yaitu 3:2 (tawas murni: produk recovery) untuk air baku I dan II sedangkan air baku III dengan perbandingan 1:1,

Tabel 13. Nilai kekeruhan dan persentase penyisihan kekeruhan berbagai dosis kombinasi

\begin{tabular}{|c|c|c|c|c|c|c|}
\hline \multirow[b]{2}{*}{ Dosis(ppm) } & \multicolumn{2}{|c|}{ Air Baku I } & \multicolumn{2}{|c|}{ Air Baku II } & \multicolumn{2}{|c|}{ Air Baku III } \\
\hline & $\begin{array}{c}\text { Kekeruhan( } \\
\text { NTU) }\end{array}$ & $\begin{array}{c}\text { Persen } \\
\text { Removal(\%) }\end{array}$ & $\begin{array}{c}\text { Kekeruha } \\
\text { n(NTU) }\end{array}$ & $\begin{array}{c}\text { Persen } \\
\text { Removal(\%) }\end{array}$ & $\begin{array}{c}\text { Kekeruhan( } \\
\text { NTU) }\end{array}$ & $\begin{array}{c}\text { Persen } \\
\text { Removal(\%) }\end{array}$ \\
\hline 35 & 1.4 & $89.23 \%$ & 1.1 & $90.00 \%$ & 2.3 & $77.00 \%$ \\
\hline 40 & 1.1 & $91.54 \%$ & 0.95 & $91.36 \%$ & 1.2 & $88.00 \%$ \\
\hline 45 & 0.9 & $93.08 \%$ & 0.8 & $92.73 \%$ & 0.95 & $90.50 \%$ \\
\hline 50 & 0.9 & $93.08 \%$ & 0.75 & $93.18 \%$ & 0.85 & $91.50 \%$ \\
\hline 55 & 0.95 & $92.69 \%$ & 0.8 & $92.73 \%$ & 0.7 & $93.00 \%$ \\
\hline 60 & 1 & $92.31 \%$ & 0.9 & $91.82 \%$ & 1 & $90.00 \%$ \\
\hline
\end{tabular}

Berdasarkan hasil analisa air baku I memiliki kekeruhan awal lebih tinggi yaitu 13 NTU, Berdasarkan hasil analisa kebutuhan dosis tawas dengan nilai kekeruhan tidak berbanding lurus. Hasil analisis menunjukan dengan kekeruhan semakin rendah membutuhkan dosis produk recovery semakin tinggi. Hal ini terlihat pada air baku III membutuhkan dosis produk recovery lebih tinggi dibandingkan dengan kondisi pada air baku I. Hal ini dikarenakan semakin rendah kekeruhan proses pembentukan flok akan semakin sulit karena TSS yang terkandung lebih sedikit sehingga memerlukan dosis yang 
lebih tinggi untuk bisa melakukan proses pengikatan flok yang lebih sempurna. Proses koagulasi dipengaruhi oleh gaya van der walls (Novita, 2001). Gaya ini merupakan gaya tarik-menarik antara dua massa (Masduqi dan Abdu, 2012). Apabila jumlah koagulannya kurang jarak antar partikel akan semakin jauh sehingga gaya tarik-menarik antar partikel tidak berlangsung maksimal dan tidak terjadi ikatan satu sama lain, sehingga penurunan kekeruhan lebih rendah. Sedangkan apabila jumlah koagulan melebihi batas optimum jarak antar partikel menjadi terlalu dekat hal ini membuat penurunan kekeruhan menjadi berkurang, sehingga mengalami kenaikan kekeruhan kembali. Selain itu, air yang memiliki kekeruhan lebih rendah membutuhkan tawas lebih banyak karena penetralan partikel oleh koagulan hanya terjadi apabila konsentrasi cukup kuat untuk proses tarik-menarik antar partikel, sehingga jarak antar partikel menjadi lebih dekat kemudian membentuk agregat yang lebih besar sehingga cepat mengendap.

\section{Hasil Analisa Biaya}

Proses recovery alum pada penelitian ini menggunakan asam sulfat dengan konsentrasi $4 \mathrm{~N}$. Konsentrasi asam menggunakan $4 \mathrm{~N}$ dengan pertimbangan agar tidak terjadi korosi pada saat penggunaan alat jar-test pada proses recovery. Upaya mendapatkan asam sulfat dengan konsentrasi $4 \mathrm{~N}$ diperlukan proses pengenceran dari asam sulfat pekat dengan konsentrasi awal $36 \mathrm{~N}$. Berikut ini perhitungan kebutuhan asam sulfat pekat untuk proses pengenceran dengan volume 500 $\mathrm{mL}$.

$$
\begin{gathered}
V_{1} \times N_{1}=V_{2} \times N_{2} \\
V_{1} \times 36=500 m L \times 4 N \\
=55 \mathrm{~mL}
\end{gathered}
$$

Pada proses recovery alum dengan menggunakan berat kering 80 gr memerlukan asam sulfat $4 \mathrm{~N}$ sebanyak $11 \mathrm{~mL}$. Lumpur yang dihasilkan dari unit clearator PDAM Karangpilang 3 sebesar 253,649 $\mathrm{m}^{3} /$ hari (Firizqy $d k k .$, 2017).

$$
253,649 \mathrm{~m}^{3}=253.649 \mathrm{~L}=253.649 \mathrm{~kg}
$$

Berdasarkan hasil analisis kadar berat kering pada lumpur sebesar $18 \%$ sehingga jumlah berat kering lumpur adalah

$$
B k=18 \% \times 253.649 \mathrm{~kg}=45.656,82 \mathrm{~kg}
$$

Berat kering lumpur clearator sebanyak $45.656 \mathrm{~kg}$ sehingga diperlukan asam sulfat dengan konsentrasi $4 \mathrm{~N}$ untuk poses recovery dengan perhitungan sebagai berikut:

$$
\begin{gathered}
\frac{V_{1}}{m_{\text {mssa }}}=\frac{V_{2}}{\text { massa }_{2}} \\
\frac{11 \mathrm{~mL}}{80 \mathrm{gr}}=\frac{V_{2}}{45.656 .000 \mathrm{gr}} \\
V_{2}=\frac{45.656 .000 \mathrm{gr} \times 11 \mathrm{~mL}}{80 \mathrm{gr}} \\
V_{2}=6.277 \mathrm{~L}(\text { asam sulfat } 4 \mathrm{~N})
\end{gathered}
$$

Sehingga berdasarkan perhitungan, kebutuhan asam sulfat yang diperlukan untuk mengolah produksi lumpur clearator dari IPAM Karangpilang 3 sebanyak $6.277 \mathrm{~L}$ asam sufat dengan konsentrasi $4 \mathrm{~N}$.

Kebutuhan asam sulfat $4 \mathrm{~N}$ kurang lebih sebanyak 6.277 L. Perhitungan kebutuhan asam sulfat pekat $36 \mathrm{~N}$ sebagai berikut:

$$
\begin{aligned}
V_{1} \times N_{1} & =V_{2} \times N_{2} \\
V_{1} \times 36 & =6.277 \mathrm{~L} \times 4 N \\
& =697,44 \mathrm{~L}
\end{aligned}
$$

B. Pengolahan lumpur $=(697 \times 97.500)$

$$
=\operatorname{Rp} 68.000 .833,-
$$




\section{Analisis Biaya dengan Penggunaan Produk Recovery}

Berdasarkan hasil analisis diketahui bahwa dosis optimum pada proses koagulasiflokulasi dengan menggunakan produk recovery adalah $50 \mathrm{mg} / \mathrm{L}$ dengan produk recovery $159 \mathrm{~mL}$. Produk recovery yang dibutuhkan untuk mengolah air baku sebanyak $1 \mathrm{~m}^{3}$ adalah 159 L. Upaya mendapatkan filtrat dengan volume $600 \mathrm{~mL}$ berdasarkan percobaan diperlukan asam sulfat $4 \mathrm{~N}$ sebanyak $11 \mathrm{~mL}$. Biaya pengolahan dengan volume air baku $1 \mathrm{~m}^{3}$ dapat dihitung dengan perhitungan sebagai berikut:

$$
\begin{aligned}
& \frac{600 \mathrm{~mL} \text { filtrat }}{11 \mathrm{mL \text {asamsulfat }} \text { }}=\frac{159.000 \mathrm{~mL}}{V} \\
& V=\frac{159.000 m L \times 11 \mathrm{~mL}}{600 \mathrm{~mL}} \\
& V=2.915 \mathrm{~mL}(\text { asam sulfat } 4 \mathrm{~N})
\end{aligned}
$$

Kebutuhan asam sulfat $4 \mathrm{~N}$ kurang lebih sebanyak $3.000 \mathrm{~mL}$. Perhitungan kebutuhan asam sulfat pekat $36 \mathrm{~N}$ sebagai berikut:

$$
\begin{aligned}
V_{1} \times N_{1} & =V_{2} \times N_{2} \\
V_{1} \times 36 & =3.000 \mathrm{~mL} \times 4 \mathrm{~N} \\
& =333 \mathrm{~mL}
\end{aligned}
$$

Biaya asam sulfat $=\left(\frac{333 \mathrm{~mL}}{1.000 \mathrm{~mL}} \times 97.500\right)$

Biaya pengolahan air baku dengan volume 1 $\mathrm{m}^{3}$ dengan dosis koagulan $50 \mathrm{mg} / \mathrm{L}$ adalah $\mathrm{Rp}$ 32.500,-

\section{Analisis biaya dengan penggunaan koagulan tawas asli}

Dosis tawas asli yang dibutuhkan pada proses koagulasi-flokulasi berdasarkan hasil percobaan adalah $50 \mathrm{mg} / \mathrm{L}$. Konsentrasi tawas yang digunakan adalah $1 \%$ atau $10.000 \mathrm{mg} / \mathrm{L}$. Sehingga untuk dosis $50 \mathrm{mg} / \mathrm{L}$ dibutuhkan tawas sebanyak $5 \mathrm{~mL}$, sehingga untuk mengolah air baku $1 \mathrm{~m}^{3}$ diperlukan tawas asli $5 \mathrm{~L}$ dengan konsentrasi $1 \%$, sehingga berat tawas yang dibutuhkan 50 gr. Biaya pengolahan dengan volume air baku $1 \mathrm{~m}^{3}$ dapat dihitung dengan perhitungan sebagai berikut:

$$
\begin{aligned}
\text { Biaya tawas asli } & =\left(\frac{50 \mathrm{gr}}{1000 \mathrm{gr}} \times 17000 / \mathrm{kg}\right) \\
& =\operatorname{Rp} 850,-
\end{aligned}
$$

Biaya pengolahan air baku dengan volume 1 $\mathrm{m}^{3}$ dengan dosis koagulan $50 \mathrm{mg} / \mathrm{L}$ adalah $\mathrm{Rp}$ $850,-$

\section{Analisis biaya dengan penggunaan kombinasi koagulan}

Proses koagulasi-flokulasi dengan menggunakan kombinasi tawas asli dengan produk recovery hasil yang optimum didapatkan pada konsentrasi tawas asli 30 $\mathrm{mg} / \mathrm{L}$ dan produk recovery $20 \mathrm{mg} / \mathrm{L}$. Pengolahan air baku dengan volume $1 \mathrm{~m}^{3}$ membutuhkan asam sulfat pekat yang dibutukan sebanyak $133 \mathrm{~mL}$ dan tawas asli $3 \mathrm{~L}$ berikut ini perhitungan biaya pengolahan air bakunya.

$$
\begin{aligned}
\text { Biaya Asam sulfat } & =\left(\frac{133 \mathrm{ml}}{1000 \mathrm{ml}} \times 97500\right) \\
& =\mathrm{Rp} 13.000,-
\end{aligned}
$$

Biaya tawas asli $=\left(\frac{30 \mathrm{gr}}{1000 \mathrm{gr}} \times 17000 / \mathrm{kg}\right)$ $=\operatorname{Rp} 510,-$

$$
\begin{aligned}
\text { Biaya total } & =R p 13.000+R p 510 \\
& =\operatorname{Rp} 13.510,-
\end{aligned}
$$

Biaya pengolahan air baku dengan volume 1 $\mathrm{m}^{3}$ dengan dosis kombinasi koagulan $50 \mathrm{mg} / \mathrm{L}$ dengan perbandingan konsentrasi 3:2 adalah Rp 13.510,- 
Berdasarkan hasil perhitungan diketahui bahwa biaya penggunaan koagulan dari proses recovery lebih mahal dibandingkan dengan menggunakan tawas asli. Namun, kelebihan biaya tersebut dapat dianggap sebagai biaya pengolahan limbah lumpur dari PDAM. Sehingga dapat mengurangi kandungan alum yang terbuang kelingkungan dan PDAM telah melaksanakan produksi bersih dan ikut mengurangi dampak buruk akibat pencemaran lingkungan dari proses produksi.

\section{KESIMPULAN}

1. Kadar Al maksimum pada proses recovery alum dengan motode asidifikasi sebesar $515,5 \mathrm{mg} / \mathrm{L}$ dengan $\mathrm{pH}$ 2. Gradien kecepatan 378.000, kecepatan pengadukan $100 \mathrm{rpm}$ dan waktu pengadukan selama 45 menit.

2. Produk hasil recovery dapat digunakan menjadi koagulan pada proses koagulasiflokulasi. Pada kombinasi untuk air baku II perbandingan konsentrasi yang paling baik dalam menurunkan kekeruhan yaitu pada perbandingan 3:2 (tawas asli : produk recovery). Hasil yang didapatkan yaitu dengen kekeruhan awal 11 NTU didapatkan nilai kekeruhan akhir sebesar 0,75 NTU.

3. Biaya penggunaan koagulan pada proses koagulasi-flokulasi dengan menggunakan produk recovery lebih tinggi yaitu Rp.32.500,- untuk menjernihkan $1 \mathrm{~m}^{3}$ air baku, menggunakan tawas asli membutuhkan biaya sebesar Rp.850,sedangkan biaya dengan menggunakan kombinasi yaitu sebesar Rp.13.510,-. Kelebihan biaya dengan menggunakan produk recovery sangat jauh dibandingkan dengan menggunakan tawas asli.

\section{DAFTAR PUSTAKA}

Cundari,Lia dkk. (2016). Pengaruh Waktu Kontak Dan Kecepatan Pengadukan Pada Asidifikasi Sludge Keluaran Water Treatment.Jurnal Teknik Kimia.19-27.

Firizqy, Maulida Ilmi. dan Serly, Oktaviani. (2017). Studi pengelolaan Lumpur Karangpilang III PDAM Surya Sembada Kota Surabaya. Laporan Kerja Praktek.Departemen Teknik Lingkungan.

Fitri, Hariana. (2012). Dampak Pembuangan Lumpur Perusahaan Daerah Air Minum Kota Pontianak Terhadap Kualitas Air Sungai Kapuas, Pontianak: Jurusan Teknik Lingkungan.

Irfan. (2007). Recovery Alum dari Lumpur Accelator IPAM Gunung Panggilun Padang. Laporan Tugas Akhir. Padang:Jurusan Teknik Lingkungan.

Masduqi, Ali dan Abdu F., Assomadi. (2012). Operasi dan Proses Pengolahan Air. Surabaya:ITS Press.

Novita,Elida. (2001). Optimalisasi Proses Koagulasi Flokulasi pada Limbah Cair yang mengandung melanoidin. Ilmu Dasar I. Vol 2, 61-67.

Ruri A,R, Boavantura. (2000). Alumunium Recovery from Water Treathment Sludge. Water supply and water quality. Internasional Conference.

Sutapa, I, D, (2014), Optimasi Dosis Alumunium sulfat dengan Poli Alumunium Clhorida untuk Pengolahan Air Sungai Tanjung Krueng Raya, Jurnal Teknik Hidraulik, 29-42. 
Wahyudin. (2001).Uji kelayakan Recovery Alum pada Lumpur hasil proses koagulasi -Flokuasi di IPAM Ngagel III Surabaya. Laporan Tugas Akhir.Surabaya: Jurusan Teknik Lingkungan. 